\title{
STUDY ON PERFORMANCE OF 80 WATT FLOATING PHOTOVOLTAIC
} PANEL

\author{
Z. A. A. Majid', M. H. Ruslan', K. Sopian', M. Y. Othman' and M. S. M. Azmi \\ ${ }^{1}$ Kulliyyah of Allied Health Sciences, International Islamic University of Malaysia, \\ 25200 Kuantan, Pahang, Malaysia \\ Phone: +609-5716400 (Ext: 3338) Fax: +609-5716776 \\ ${ }^{2}$ Solar Energy Research Institute (SERI), Universiti Kebangsaan Malaysia, \\ 43600 Bangi, Selangor, Malaysia \\ Email: amzafri@iium.edu.my
}

\begin{abstract}
Photovoltaicpanels are used to generate electric power. The surface temperature of the photovoltaic (PV) panels will affect theirefficiency, where the increment of temperature will decreasetheir efficiency and total power gain. In this study, we will discuss the performance of an $80 \mathrm{~W}$ floating photovoltaic (PV) panel in a pond simulator, whereby in a two hour experiment it shows up to $15.5 \%$ increment of energy gain compared to a normal photovoltaic (PV) panel. The floating photovoltaic (FPV) panel was designed by replacing the photovoltaic panel frame with a material that has the ability to float on a water surface and is capable of transferring heat at the back of the photovoltaic surface. A heat sink is used to transfer heat at the bottom of the photovoltaic panel, which will decrease the surface temperature when placed on the water surface. The best performance of the photovoltaic panel is $1000 \mathrm{~W} / \mathrm{m}^{2}$ fora surface temperature of $25^{\circ} \mathrm{C}$; however,the efficiency will drop by $0.485 \%$ per $1{ }^{\circ} \mathrm{C}$ temperature increment.The system can be used on lakes, ponds or dams.
\end{abstract}

Keywords: Floating photovoltaic; heat transfer; efficiency; performance.

\section{INTRODUCTION}

Photovoltaic systems produce the most popular renewable energy in generating electric power for application in residential contexts. Wind power, geothermal and hydroelectric are more suitable for huge power generators and buildings such as electric power plants.However, the main problem with photovoltaic systems is their relatively low efficiency[1]. Most commerciallyavailable photovoltaic panels manage to convert only 6 $\%-18 \%$ ofthe incident radiation falling on them into electrical energy [2]. The best performance by a photovoltaic panel is documented by Sharp Cooperation [3] at 1000 $\mathrm{W} / \mathrm{m}^{2}$, fora surface temperature of $25^{\circ} \mathrm{C}$, wherethe efficiency will drop by $0.485 \%$ per 1 ${ }^{\circ} \mathrm{C}$ temperature increment. The rest of the incident radiation is lost by reflection or as thermal energy. Some of the thermal energy is absorbed by the cells, leading to a decrease of the panel's efficiency.In fact,the temperatures reached by PV cells are higher than theambient temperature [4]. The ambient temperature in Malaysia is $33{ }^{\circ} \mathrm{C}$ at a solar radiation of $1100 \mathrm{~W} / \mathrm{m}^{2}$, which increases the photovoltaic surface temperature to $55^{\circ} \mathrm{C}$. The important role of the operating temperature in relation to the electrical efficiency of a photovoltaic (PV) device, be it a simple module, a PV/thermal collector 
(PV/T) or a building-integrated photovoltaic (BiPV) array, is well established, as can be seen from the attention it has received from the scientific community [5].

Photovoltaic cells will exhibit long-term degradation if the temperature exceeds a certain limit. Photovoltaic cells are the heart of photovoltaic water pumping systems. In order to utilize PV power and increase photovoltaic water pumping system efficiency, it is necessary to keep the PV cell temperature and cell reflection as low as possible. Abdolzadeh and Ameri [6] investigated the possibility of improving the performance of a photovoltaic water pumping system by spraying water over the photovoltaic cells. The results are compared with traditional systems. Experimental results show that the cells' power is increased by this spraying. This can significantly increase the system and subsystem efficiency as well as the pump flow rate when operating under different heads. Measurements of the short circuit current of the module, which is nearly temperature-independent, indicated that the water spray improved the system's optical performance. Researchers at Kyushu University in Japan are developing a large-scale atsea power plant combining photovoltaic cells and windmills designed to match the output of a nuclear power reactor. About 200,000 photovoltaic generator units are to be placed about a meter apart on the netting, with hexagonal units positioned at both ends. The units have a channel running through them to allow seawater to pass through. Each group of units will generate about $300 \mathrm{MW}$ of electricity, which means the generating capacity of the three planned sets will be equal to that of a nuclear power reactor [7].

Tripanagnostopoulos et al. [8] found that the cooling provided by the thermal integration assistedin improving the efficiency of the PV cells by approximately $10 \%$. They also foundthat water cooling providedbetter cooling than air circulation.Tonui and Tonui and Tripanagnostopoulos [9] highlighted that the photovoltaic (PV) cells suffer a drop in efficiency as their operating temperature increases, especially under high insolation levels. Reducing the operating temperature by cooling the cells will improve their performance. They used a suspended thin flat metallic sheet at the middle or fins at the back wall of an air duct as heat transfer augmentations in an air-cooled photovoltaic/thermal (PV/T) solar collector to improve its overall performance. Anderson et al. [10] discussed two methods to improve both the thermal and electrical efficiency. First, it can be improved by maximizing the ratio of the cooling tube width to spacing. Second, by using thermally conductive adhesives, good thermal contact between the PV cells and the absorber can be achieved. Dubey et al. [11] tried to improve the overall electrical efficiency of the photovoltaic (PV) module by reducing the temperature of the PV module by withdrawing the thermal energy associated with the module. This was done by considering four different configurations of two types of PV modules. In order to increase the efficiency of the PV module, a study on the frame of the photovoltaic panel was conducted. In this study, we designed the frame of a photovoltaic panel which is able to float on water and is capable of transferring heat at the back of the photovoltaic surface. The performance of the system will be analysed.

\section{METHODOLOGY}

The system is divided into three main components; polyvinyl chloride (PVC) pipe is used as a buoy, hollow square aluminium as the heat sink and the photovoltaic panel as the power generator. The solar panel used is an $80 \mathrm{~W}$ multicrystallinemodel (Sharp NE80E2EA). This model has dimensions of $1200 \mathrm{~mm} \times 537 \mathrm{~mm}$ and a weight of $7.5 \mathrm{~kg}$. The original frame of the solar panel, made of aluminium will not be used, but replaced with PVC pipe. The PVC pipe used is $110 \mathrm{~mm}$ in diameter and connectedas a circular 
loop with four elbow connectors each $120 \mathrm{~mm}$ in diameter. This structure will enable the PVC pipe to trap air while not allowing water to enter, which eventually makes it into a buoy. PVC pipe is used because it is not biodegradable and can be used for a very long time. The system is corrosion-free. The physical properties such as tensile strength are high, and can be developed to be combined as a huge floating PV system. The heat transfer mode applied is conduction. The material chosenis hollow square aluminium with dimensions $60 \mathrm{~mm} \times 45 \mathrm{~mm}$.Seven units of hollow square aluminium were used, tied together in parallel and hungon the PVC pipe. The photovoltaic panel is placed on top of the hollow square aluminium, as in Figure 1. Aluminium is the most suitable material, chosen based on its thermal conductivity, material density and cost considerations. A comparison of the thermal conductivity and density value of the materials is shown in Table 1. Copper is not used, although its thermal conductivity is higher than aluminium, because it is expensive, denser and hence heavier than aluminium. Although stainless steel is a good material, its low thermal conductivity and high density are not suitable for the system. Apart from its density and thermal conductivity, the property of aluminium which is non-corrosive to pure water makes it the best material to use for the system. The Sharp photovoltaic panel is chosen because of its lamination style, which coversthe upper and lower surfaces.The area surrounding the panelis gripped, preventing water from enteringthe solar cell (waterproof).

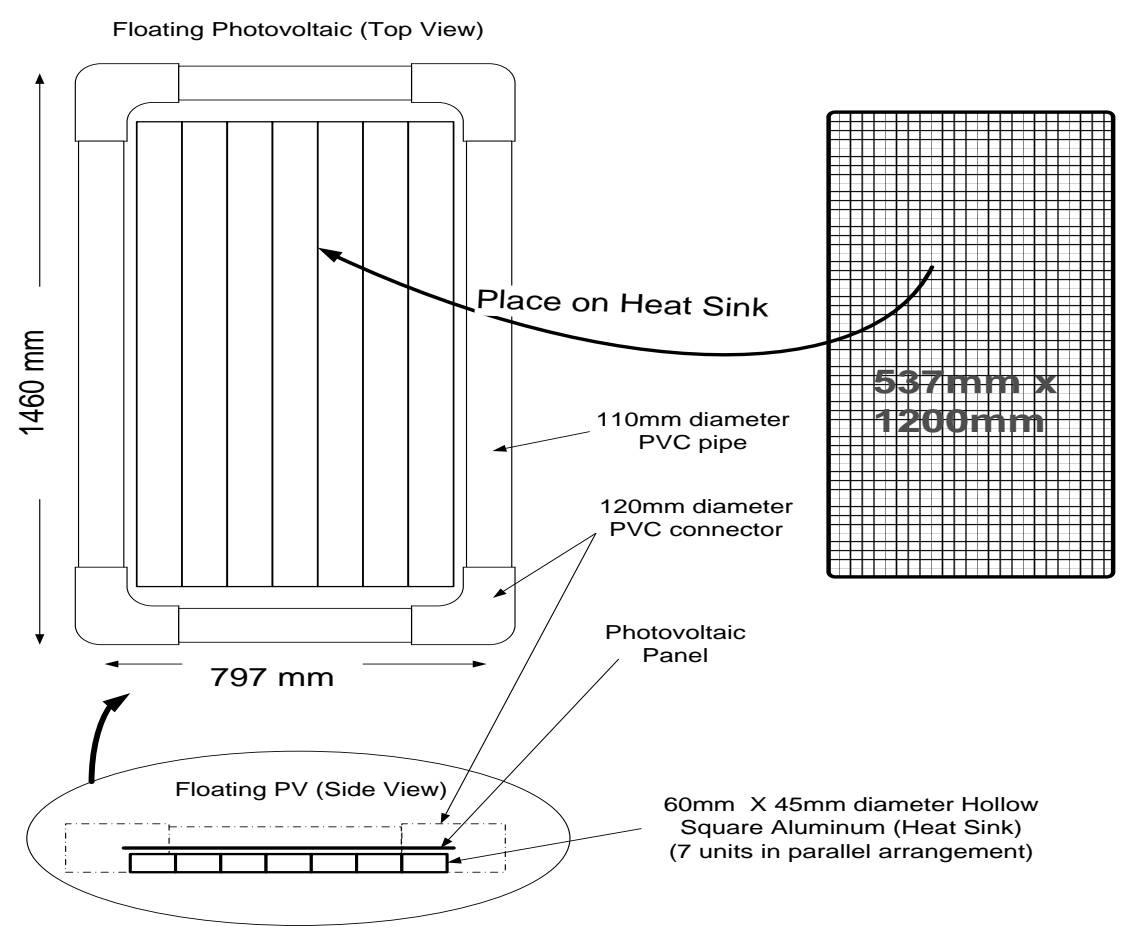

Figure 1. Proposed design of FPV.

The photovoltaic panel, which is attached on the parallel arrangement of aluminium together with the PVC pipe, is placed horizontally on the water surface without any tilt angle. Since Peninsular Malaysia is located in the Tropics at a latitude of $1.33^{\circ} \mathrm{N}$ to $6.67^{\circ} \mathrm{N}$ and longitude of $99.58^{\circ} \mathrm{E}$ to $103.33^{\circ} \mathrm{E}$, maximum exposure of sun's radiation on the photovoltaic panel required a tilt angle between $0^{\circ}$ and $7^{\circ}$; the best orientation is for the tilt angle to follow the latitude position. However, for the FPV system, $0^{\circ}$, the horizontal position, is preferred so as to ensure maximum heat transfer through conduction between the PV panel and aluminium, which is eventually 
transferred to the water for the cooling process to happen. The tilt angle of the solar panel is not a critical issue, since the experiment is done in a tropical region. Solar irradiation in the Tropics is greater than in other regions of the northern or southern hemispheres. The experiment is conducted in a pond simulator. The pond simulator is a 5800 litre container filled with water and supplied with a continuous flow of water. The continuous water flow is necessary to ensure that the ambient temperature is maintained at $25^{\circ} \mathrm{C}$. The experiment is conducted at peak hours of solar radiation from 11.00 am to $1.00 \mathrm{pm}$, which is in order to evaluate the effect of the PV surface temperature on the performance of the PV due to changes in solar radiation. The first experiment was done on a normal photovoltaic (PV) panel and the second experiment onthe FPV the next day. The chosen load was an $8 \mathrm{Ohm}$ resistor for both experiments. Both experiments used the same photovoltaic panel to control the variables so as to ensure a precise comparison of the data.

Table 1. Properties of materials.

\begin{tabular}{lcc}
\hline Material & $\begin{array}{c}\text { Density } \\
\left(\mathrm{kg} / \mathrm{m}^{3}\right)\end{array}$ & $\begin{array}{c}\text { Thermal conductivity } \\
(\mathrm{W} / \mathrm{mK})\end{array}$ \\
\hline Copper & $8920-8960$ & 380 \\
Aluminium & 2712 & 220 \\
Stainless steel & $7480-8000$ & $12.11-45.0$ \\
\hline
\end{tabular}

\section{RESULTS AND DISCUSSION}

Experimental results were obtained by using the ADAM VIEW program. The overall results show the increment of power gain by the photovoltaic panel when floating on water with the heat sink at the bottom. The experiments were done on two separate days during which the amount of solar radiation and fluctuation of temperature should be the same to produce the same conditions, resulting in less difference between experiments. Fluctuation of solar radiation will not vary the surface temperature of photovoltaic abruptly. Majid et al. [12] have done an experiment on the floating PV and shown that, with solar radiation of $1100 \mathrm{~W} / \mathrm{m}^{2}$ and a pond simulator temperature of $25^{\circ} \mathrm{C}$, the FPV temperature increases to $41^{\circ} \mathrm{C}$ and the normal (PV) increases to $51{ }^{\circ} \mathrm{C}$. The FPV shows an increment of $8^{\circ} \mathrm{C}$ while the normal PV shows a very substantial increment of $18^{\circ} \mathrm{C}$ from the initial temperature of the PV panel, which was $33^{\circ} \mathrm{C}$. The power gain of the FPV shows an increment, but at lower load the difference is not obvious. The increment of load used givesa larger difference and at peak power the FPV gives $76.61 \mathrm{~W}$, while the normal PVgives $72.32 \mathrm{~W}$, a difference of $4.29 \mathrm{~W}$, and an increase by $5.93 \%$ of the normal PV's power gain. The long-term performance also shows similar results, with a higher difference of the increment of the normal PV, and the floating PV surface temperature showing a lower value, as shown in Figure 2. The results show that in the two hour experiment from 11.00 am to $1.00 \mathrm{pm}$ the normal PV increased its average temperature to $60.7^{\circ} \mathrm{C}$, while the average ambient temperature at this time was $30.0^{\circ} \mathrm{C}$. The average temperature of the floating $\mathrm{PV}$ is $46.6^{\circ} \mathrm{C}$ in the same ambient temperature condition. This demonstrates the floating PV's success in reducing the heat of the surface of the photovoltaic panel. The difference of increment indicates that the FPV panel is cooled by the cooling technique applied. On the other hand, these results show that the heat from thesurface of the photovoltaic panel is transferred to the pond simulator, and reduces the photovoltaic temperature; the pond simulator acts as a cold reservoir and is used as a cooling system. Note that the temperature of the PV panel increased mainly due to the heat provided by solar radiation, but partly also due to the current flow in the solar cell. For the crystalline type of photovoltaic panel, the total power gain will reduce by $0.485 \%$ per $1{ }^{\circ} \mathrm{C}$ temperature increment. 
The temperature of the solar panel will have an effect on the total energy gain, where the normal PV produces a lower value than the floating PV, as shown in Figure 3. The average energy produced by the floating PV is $1190 \mathrm{~W}$ in average solar irradiation of $896 \mathrm{~W} / \mathrm{m}^{2}$ and the normal PV produces $1030 \mathrm{~W}$ in average solar irradiation of $940 \mathrm{~W} / \mathrm{m}^{2}$ in the two-hour experiment, which means that the average total energy gain by the FPV panel is $15.5 \%$ higher than the normal PV panel. If the average daily solar irradiance is $5000 \mathrm{~W} / \mathrm{m}^{2}$, this will produce up to $77.5 \%$ greater energy gain by the floating PV than the normal PV, proving that the performance of the floating PV generates a higher energy gain. Furthermore, the roof temperature could increase up to $65^{\circ} \mathrm{Con}$ a hot and sunny day, when heat is trapped in the roof top. The efficiency of the photovoltaic panel will decrease tremendously, resulting inup to $19.4 \%$ of power gain lost from the system.

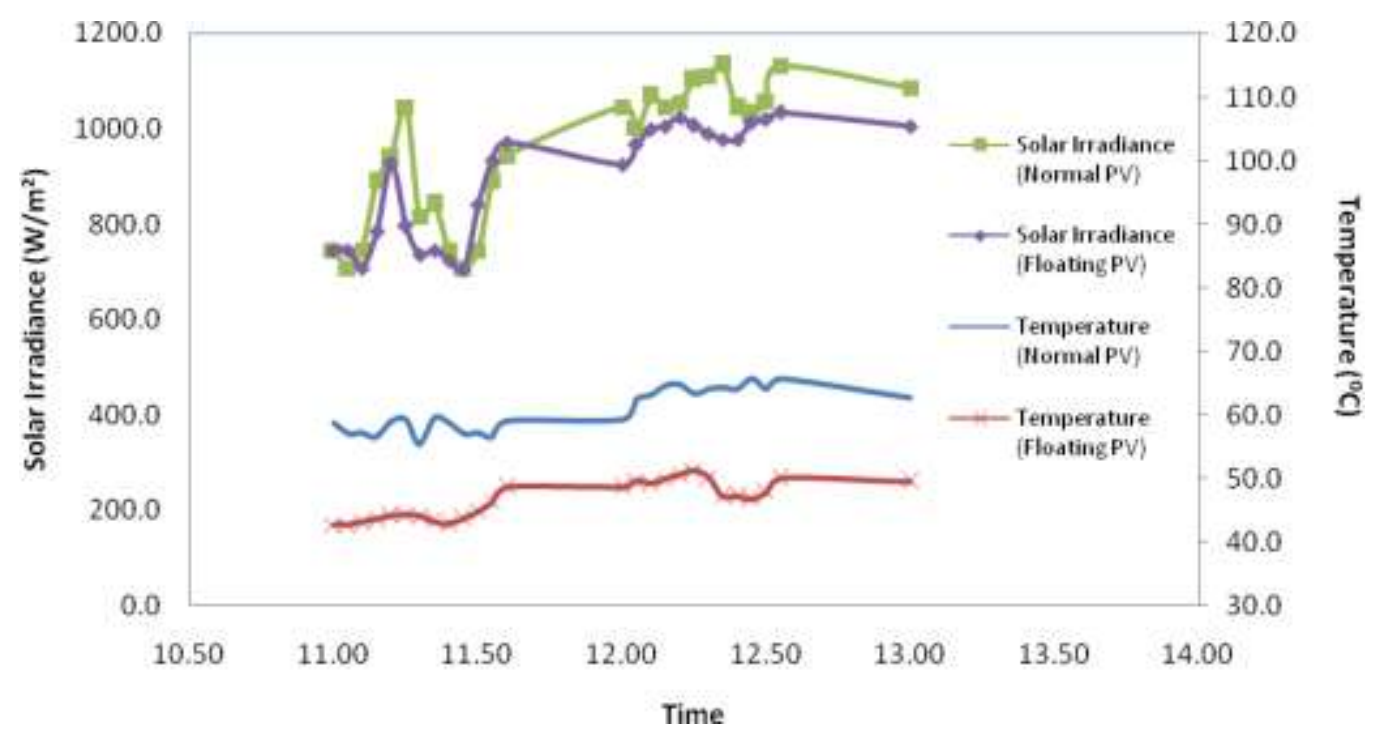

Figure 2.Temperature difference between floating PV and normal PV under solar irradiance from 11.00 am to $1.00 \mathrm{pm}$.

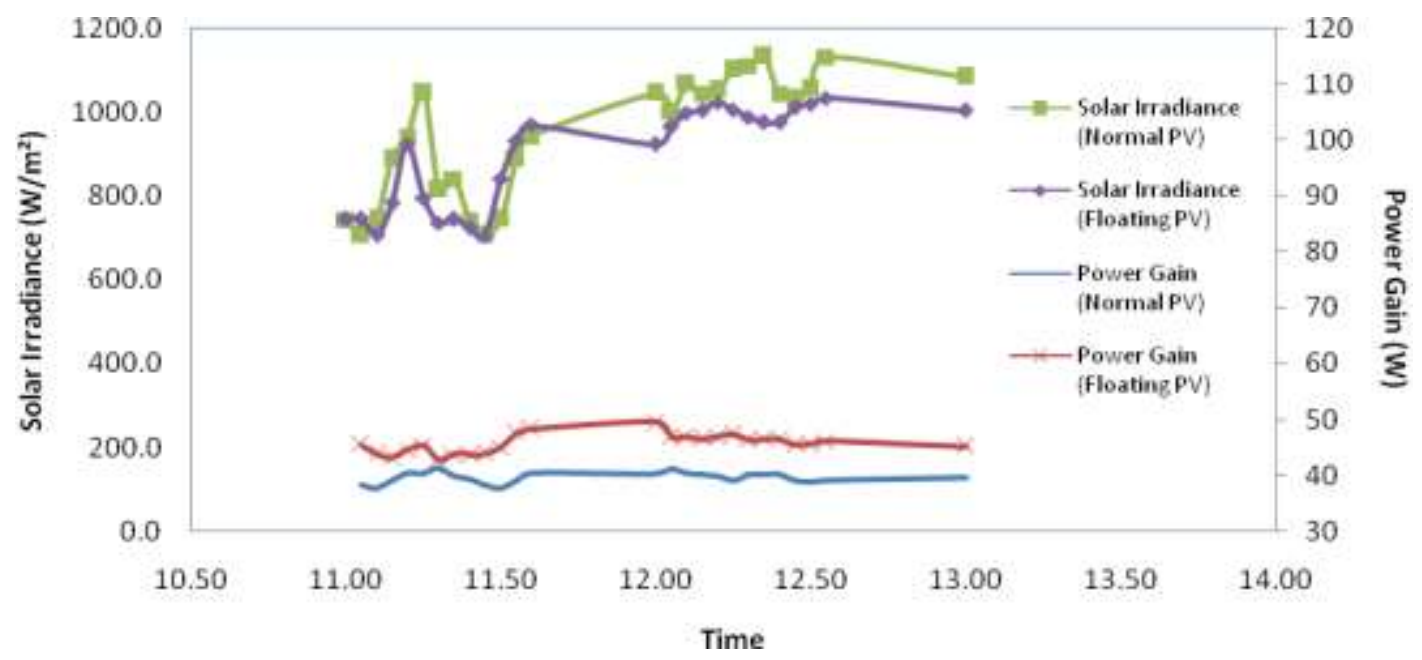

Figure 3. Energy gain difference between floating PV and normal PV under solar irradiance from 11.00 am to $1.00 \mathrm{pm}$. 
This system is suitable for Malaysia, because Malaysia has only one season throughout the year. It is also applicable in any other countries in the tropical region. Forcountries that have four seasons, this technology is not suitable as the solar irradiation values vary throughout the year. The tilted angle of the photovoltaic panel needs to be adjusted to get the maximum exposure to solar radiation. Apart from that, ice on the water in winter will break the photovoltaic panels. One of the applications is at dams, an appropriate place for developing FPV power plant, as besides supplying water it can also be usedto generate electric power. The water surface covered by PV panels will reduce water evaporation due to heat from the sun, which isunable to heat the water surface directly, this being only applicable to large-scale systems, however.Besides generating power, this type of technology is able toretain water for a longer time, by reducing surface water evaporation. This technology will multiply the functions of the dam, not just mainly to supply water but also to generate electricity.The materials used to develop the system can be easily obtained from local markets, thus reducing the development cost, which makes it suitable for commercialization and local manufacture.

\section{CONCLUSIONS}

The FPV panel shows an increment in photovoltaic efficiency. At a solar radiation of $1100 \mathrm{~W} / \mathrm{m}^{2}$ the power gain by the photovoltaic unit increases to 5.93\%. The design and fabrication of the PV system proves that it can increase the PV efficiency by reducing the PV temperature. Referring to these conditions, the FPV system is one solution to reduce the cost of photovoltaic installation and the space it requires, increasing the photovoltaic panel efficiency and providing an environmentally friendly technology, as it has less impact onthe land.It has been proved that in two hours of testing under solar radiation the power gain for the floating PV panel increased by $15.5 \%$ compared to the normal PV unit.

\section{ACKNOWLEDGEMENTS}

The authors would like to thank the International Islamic University of Malaysia, Solar Energy Research Institute (SERI) Universiti Kebangsaan Malaysia and Ministry of Higher Education of Malaysia for financial assistance for this research project.

\section{REFERENCES}

[1] Omer AM. Built environment: Relating the benefits of renewable energy technologies. International Journal of Automotive and Mechanical Engineering. 2012;5:561-75.

[2] Bazilian MD, Leenders F, van Der Ree B, Prasad D. Photovoltaic cogeneration in the built environment. Solar Energy. 2001;71:57-69.

[3] Sharp C. 80W Polycrystalline silicon PV module. NE80E2EA2007.

[4] Ruslan MH, Othman MYH, Sopian K, Majid ZAA, Him WA. Development of photovoltaic-thermal (PV/T) water based system. World Renewable Energy Congress (WREC X). Glasgow, Scotland2008 p. 1853-7.

[5] Skoplaki E, Palyvos J. Operating temperature of photovoltaic modules: A survey of pertinent correlations. Renewable Energy. 2009;34:23-9.

[6] Abdolzadeh M, Ameri M. Improving the effectiveness of a photovoltaic water pumping system by spraying water over the front of photovoltaic cells. Renewable Energy. 2009;34:91-6.

[7] Shimbun Y. Development of a massive environmentally friendly power plant combining 
photovoltaic generators and windmills that will float. Green Car Congress: http://www.yomiuri.co.jp/dy/national/20080830TDY04305.htm; 2008.

[8] Tripanagnostopoulos Y, Nousia T, Souliotis M, Yianoulis P. Hybrid photovoltaic/thermal solar systems. Solar Energy. 2002;72:217-34.

[9] Tonui J, Tripanagnostopoulos Y. Improved PV/T solar collectors with heat extraction by forced or natural air circulation. Renewable Energy. 2007;32:623-37.

[10] Anderson TN, Duke M, Morrison G, Carson JK. Performance of a building integrated photovoltaic/thermal (BIPVT) solar collector. Solar Energy. 2009;83:445-55.

[11] Dubey S, Sandhu G, Tiwari G. Analytical expression for electrical efficiency of PV/T hybrid air collector. Applied Energy. 2009;86:697-705.

[12] Majid ZAA, Ruslan MH, Othman MYH, Sopian K. Design and application of floating photovoltaic (FPV) in Malaysia. Seminar on Progress of Solar Energy Research and Development. Universiti Kebangsaan Malaysia, Bangi2008. p. 259-64. 